\title{
The Paradigm of Fuelwood Consumption around National Parks and Its Implication for National Policies: The Case of Nech Sar National Park, Ethiopia
}

\author{
Molla Mekonnen Alemu \\ University of Leicester, Leicester, UK \\ Email: mollamekonnen@gmail.com
}

How to cite this paper: Alemu, M.M. (2017) The Paradigm of Fuelwood Consumption around National Parks and Its Implication for National Policies: The Case of Nech Sar National Park, Ethiopia. Open Access Library Journal, 4: e3385.

https://doi.org/10.4236/oalib.1103385

Received: December 28, 2016

Accepted: January 22, 2017

Published: February 6, 2017

Copyright ( 2017 by author and Open Access Library Inc.

This work is licensed under the Creative Commons Attribution International License (CC BY 4.0).

http://creativecommons.org/licenses/by/4.0/

(c) (i) Open Access

\begin{abstract}
Forests are vital land resources as they provide some of the essential goods and services for the sustenance of human life. In many developing countries, local communities still rely on forests as their prime source of energy in the form of fuel wood and charcoal. This phenomenon has also let many men and women to rely on fuelwood collection and charcoal making as their main stay of livelihoods. In line with this, in many instances, forests of National Parks are still going through illegal and immense deforestation actions as a result of the energy demand by the local communities. Nech Sar National Park, a jewel in the Rift Valley region of Ethiopia is also being affected by deforestation as it shares an immediate border with the city of Arba Minch, one of the heavily populated cities in the southern part of the country and heavily relies on the forest of the park for meeting the household energy demand of its inhabitants. This study was done to quantify the amount of fuelwood which comes out of the park and explore the severity and magnitude of the problem. Primary data on the amount of fuelwood were collected from the three major outlets of the park. Questionnaire and interviews were used to collect information from the local communities, the concerned local authorities, the operational and management staff of the park. Every day, an average of 2909 bundles of fuelwood comes out of the park, fuelwood collection being dominated by females. Therefore, alternative energy sources and energy saving stoves, environmental awareness development for the wider community members and the creation of alternative livelihood opportunities should be in place if the precious land resources of the park have to be conserved.
\end{abstract}

\section{Subject Areas}

Environmental Economics, Marketing 


\section{Keywords}

Forest, Fuelwood, Nech Sar, Parks

\section{Introduction}

Humans depend on the natural resources for their subsistence. Apart from their ecological functions, forest resources are the sources timber, shelter for wildlife, means of livelihoods, tourism, construction materials and potential sources of food in many instances. In many parts of the world, forests are also the principal sources for the household energy demand.

Ecologically, forests play a significant role in conserving soil and water resources. Surface runoff and soil erosion are very minimal in forested areas as the velocity and intensity of water movement will be lowered down by the foliage, barks and roots of the trees. As a result of high concentration of humus in forested areas duet to the leaf fall, infiltration rate of water is much higher to help the recharging of underground water. Forests also play in moderating local and regional adverse climatic conditions as they sequester carbon and other toxic elements from the atmosphere. They also ameliorate local climatic conditions by controlling the velocity of wind. Forests also provide shelter for the ecologically and economically important resources like wildlife, natural habitats along with their biological diversity.

From economical perspectives, forests also provide livelihood opportunities for many through the production of timber and non-timber products. The tourism industry is also highly reliant on the existence of forests and its associated services. Agricultural farm lands located in the nearby of forests are also mentioned to have an increased productivity through the reduction of soil erosion and reduced damage from high wind speed [1].

Edible fruits, oil extracts, leaves, tubers and rhizomes are among the sources of food for mankind in many parts of the world. Forests are also the sources of food from caterpillars, insects and bush meat [2].

Fuelwood is the prime source of household energy for about 2 billion people around the world [3] by providing heating, cooking and other energy demands for many generations and this accounts for about $54 \%$ of the annual deforestation rate [4] [5]. Carlos and Khang [6] mentioned that $10.4 \%$ of the global energy and about $77.4 \%$ of the global renewable energy supply are coming from forest resources. Fuelwood collection is considered to be a responsibility of women in many developing countries, which adds extra burden on women as fuelwood collection is a time and energy demanding activity [7].

More than $90 \%$ of the total annual energy source of Ethiopia comes from biomass [8]. This proportion is projected to continue for the years to come as the major portion of the country's population lives in rural areas that have less access to other alternative sources of energy, charcoal and fuelwood being the principal sources. According to Araya and Yissehak [9], the production of char- 
coal has increased from a million tons to more than three million tons per annum and the consumption of fuelwood has also increased from forty million to one hundred million cubic meters per annum. This all has led the degradation of the forest and its associated resources of the country.

As a result of the deficiency in alternative energy sources of the area, about 98\% of the city of Arba Minch inhabitants are dependent on fuel wood and charcoal as their primary sources of the household energy. The lion's share of this supply is also coming from the forests of Nech Sar National Park [10]. This practice has led to the destruction of the park's ecological capital and the services they provide. This study is, therefore, aimed at exploring the magnitude of the fuelwood extraction from the park and suggests possible solutions which will help the conservation of the natural resources of the park.

\section{Methodology}

\subsection{Description of the Study Area}

Nech Sar national park is one of the earliest national parks in Ethiopia. It was established in 1974 as a result of its natural beauty and a large number of wild animals. The park is situated in the Southern Nations and Nationalities Regional State of Ethiopia right after the eastern edge of Arba Minch town, at about 510 $\mathrm{Km}$ south of Addis Ababa and $270 \mathrm{Km}$ from Hawassa. The park lies within the floor of the Great Rift Valley and extends from $5^{\circ} 51^{\prime} \mathrm{N}$ to $6^{\circ} 50^{\prime} \mathrm{N}$ and from $37^{\circ} 32^{\prime} \mathrm{E}$ to $37^{\circ} 48^{\prime} \mathrm{E}$ with an elevation varying between 1108 and 1650 above sea level. It covers an area of $514 \mathrm{Km}$ of which $85 \%$ is land and $15 \%$ is water (shores of Lake Abaya from the north and Lake Chamo in the south) [10]. The "Bridge of God", a narrow piece of land separates Lake Chamo and Lake Abaya, both of which are located in the craters of ancient volcanoes. The eastern border of the park extends to include the plains at the foothills of the spectacular Amaro Mountains. In the far eastern part of the park, hot springs bubble to the surface (Figure 1).

Nech Sar National Park is also endowed with a diverse range of forest resources which includes the dense Ground water forest which covers an area of 7500 ha (14.59\% of the park) (mainly dominated by Lonchocarpus laxiflorus, Euclea divinorum, Prunus africana Maytenus undata and Syzygium guineense); the Dry forest-woodland-bush land, a thick and impenetrable in places, the taller trees including Combretum spp., Dichrostachys cinerea, Acacia tortilis, Balanites aegyptiaca and occasional Acacia nilotica that covers about 5100 ha or $9.92 \%$ of the park; and the Shrub land or thorn savanna which is characterized by vegetation dominated by shrubs, often also including grasses and herbs whereby $D o$ bera glabra and Acacia tortilis are common and covers about 11,500 ha or $22.37 \%$ on the higher parts of the hills of the land bridge and the mountains east of the plains [12] [13].

\subsection{Data Collection and Analysis}

After having a reconnaissance survey to identify the major routes which is being 


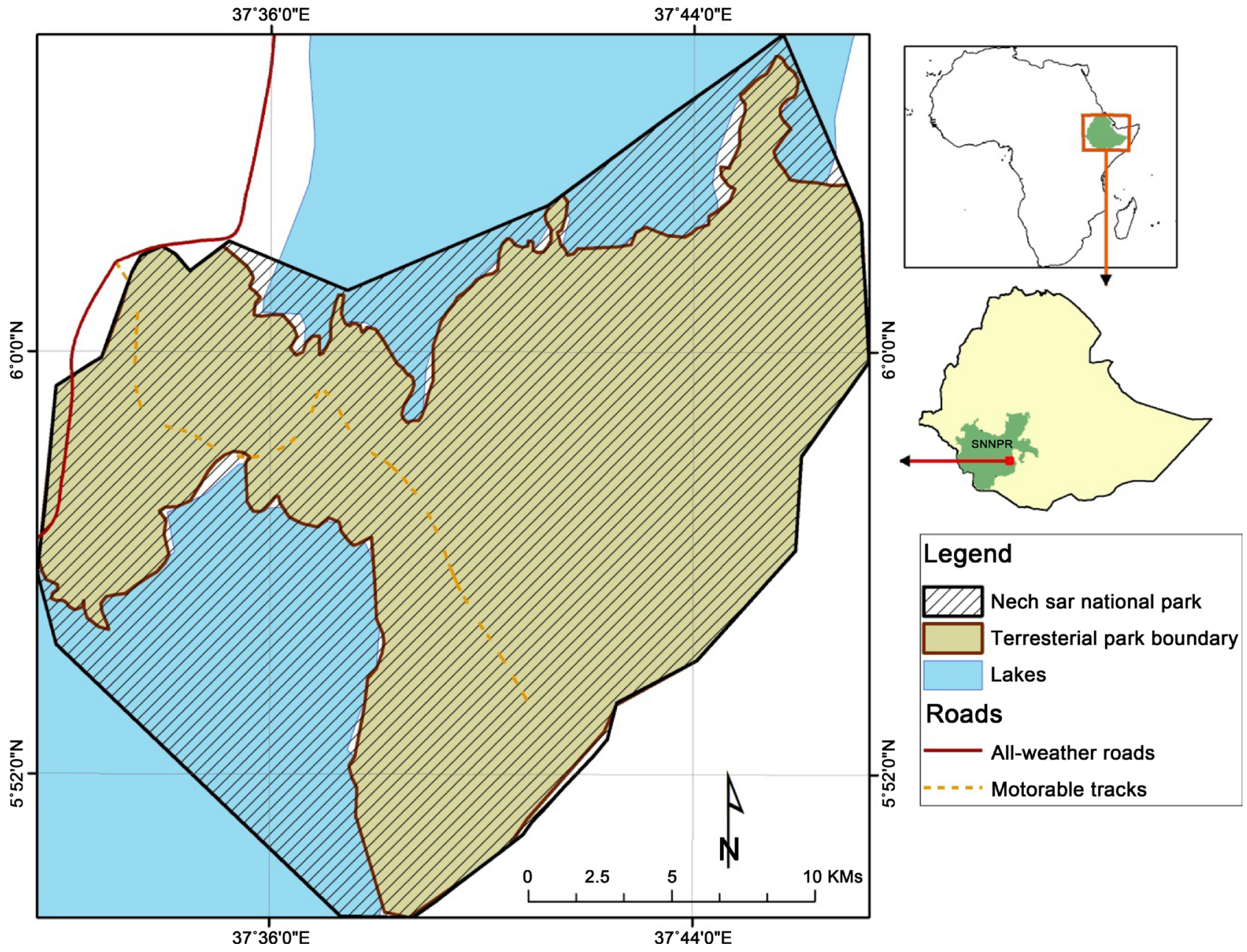

Figure 1. Location map of Nech Sar National Park [11].

used by the fuelwood collectors, it was identified that they use three major outlets namely, Highland, Kulfo Bridge and the Jinka road to enter the park territories and do the fuelwood collection activities by cutting the precious forest resources. Accordingly, data on the fuelwood collection was collected on the basis of the gender, age category, timing and volume of the wood per person. To estimate the volume of the fuelwood carried by each person, a sample of 3 commonly practiced bundles were measured initially and a category 20 - $30 \mathrm{~kg}, 31$ $40 \mathrm{~kg}$ and $41-50 \mathrm{~kg}$ were set accordingly so as to visually estimate the volume of the fuelwood which comes out of the park by each collector. For the age category; collectors which appear to be under the age of 25 were categorized under the youth group, those who appear to be between 26 - 50 as adult, and those who appear to be beyond 50 were categorized as old. Reports and literatures were also reviewed as source of information. Information was collected for 20 consecutive days from 6AM in the morning until 8:30 PM in the evening. Primary data were also collected from 53 (34 female) inhabitants of Arba Minch city, community members and Government officials by making use of interviews and questionnaire. Data was then transcribed and analyzed by making use of an excel sheet and content analysis. 


\section{Results and Discussion}

About $98 \%$ of Arba Minch inhabitants are reliant on fuelwood as their major source to meet their household energy demand [10], Nech Sar National Park being the prime source for it. $94 \%$ of the respondents mentioned that the fuelwood comes totally from the Park while the rest of the respondents mentioned that the neighboring mountains are additional sources for the fuelwood supply of the city. Trees (both live and dead), and branches are being cut from the Ground Water Vegetation of the park in an illegal way. Though the Park is exerting its capacity for the protection of the forest and its associated resources, the fuelwood collectors will always find their way to do their regular duty. As can be seen from Figure 2, in some of the inaccessible and hidden pockets of the park, it is not uncommon to see the smokes of charcoal making during the evening as the Park Rangers will not be on duty by then. The human and financial resources of the Park are not in a position to support the patrolling activities of the entire ecosystem.

As the cost of fuelwood and charcoal is increasing from time to time, about $55 \%$ of the respondents mentioned as they are using improved stoves for cooking and heating purposes. But, there are also many who still use the traditional stoves of putting 3 stones and burn the fuelwood openly which results in the wastage of the energy that could have been used efficiently (Figure 3 ).

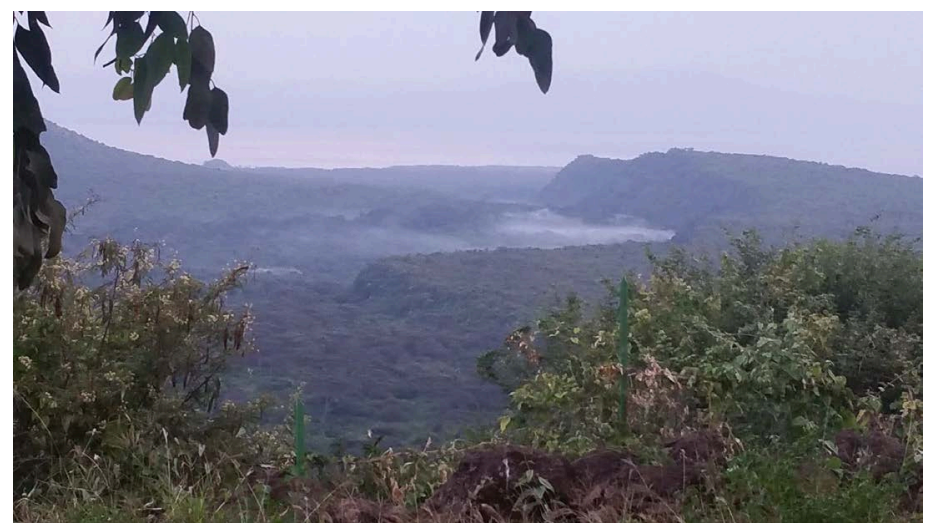

Figure 2. Charcoal making smokes inside the ground water vegetation of Nech Sar National Park.
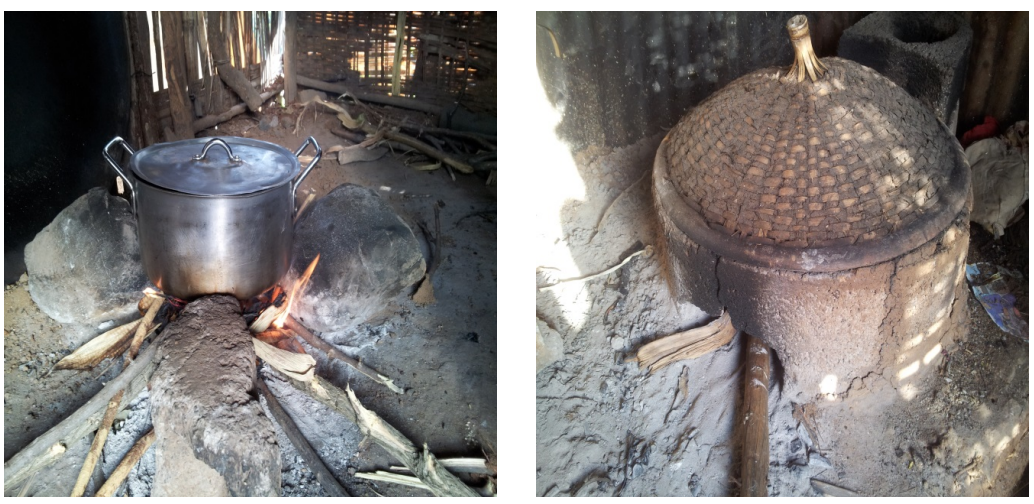

Figure 3. Traditional stove (left) and fuel saving stove (right). 
According to the Zone Water, Mines and Energy Office [14], in the city of Arba Minch and the Arba Minch Zuriya district in general, there are only 3 fuel saving stove producer cooperatives with a total of 22 female and 3 male members that are established with support from GIZ and VITA. The number of cooperatives, however, when compared to the total population of the city $(74,879$ in the city and Arba Minch Zuriya district 164,529) [15] is a very low capacity so as to meet the increasing energy demand as well as to do the market promotion works of the products to the wider community. This indicates as the concerned government authorities should enhance the energy provision sector if the remaining natural resources of the park that have local, regional and global role have to be saved from extinction.

Due to the low level of awareness by the community, people who are engaged in this kind of pottery activities will also have lower strata within the society since traditionally people who engaged in handcrafts activities are believed to be from a lower class segment of the community who are not well to do since their ancestors. In the case of Arba Minch, for instance, these handicrafts are called "Maze" which has its own pejorative tone in undermining the nature of the work itself. This type of work is also usually considered a women's job and the involvement of men in this activity is very minimal. However, given the very labour demanding nature of the work, awareness development works should have helped to increase the level of engaging more men in the sector.

The results of the fuelwood survey showed as a huge number of trees (Table 1) will be cut every day from the park. If the protection efforts are not intensified in a collaborated way and the current trend continues, the biodiversity potential of the Ground Water Vegetation of the Park which has ecological as well as local and regional economic importance will vanish from the surface of the ground. Law enforcement, creation of alternative livelihood opportunities and the provision of alternative energy sources are also some of the issues that has to be considered by the Governmental and other developmental partners as a matter of urgency.

Since a large proportion of women are being engaged in the fuelwood collection (Figures 4-6) and the traditional consideration of cooking activities as a women job by the society, massive awareness development activities have to be held in a productive way so as to counteract this traditional harmful attitudes as well as practices.

Table 1. Average amount of fuelwood being extracted from the park.

\begin{tabular}{cccc}
\hline S.N & Fuelwood collection pattern & *Amount/M & Number of trees used \\
\hline 1 & Daily & 457 & 152 \\
2 & Monthly & 13,710 & 4570 \\
3 & Biannually & 82,260 & 27,420 \\
4 & Annually & 164,520 & 54,840 \\
\hline
\end{tabular}

*3 individual trees with an average height of 5 meters and basal diameter of $30-40$ centimetres are estimated to account for a $\mathrm{M}^{3}$ of wood. 

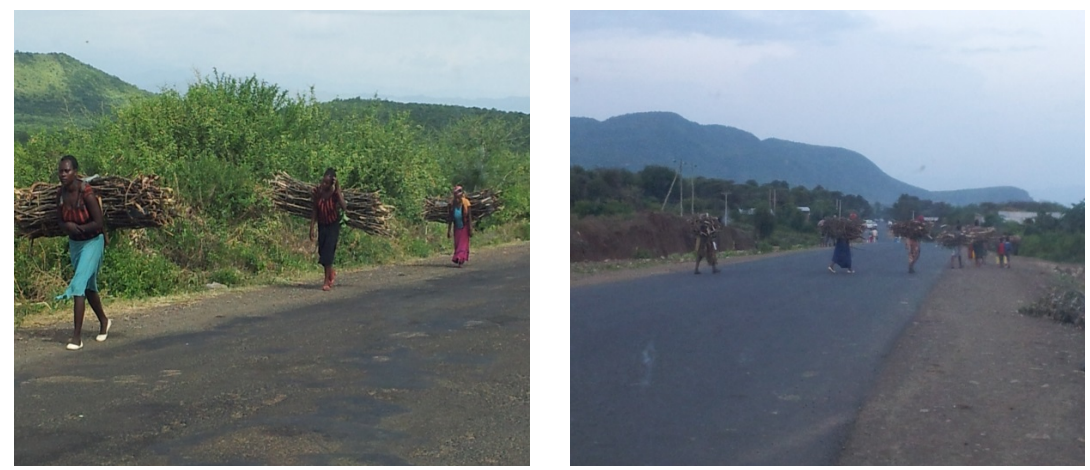

Figure 4. Female fuelwood collectors on their way to home and market.

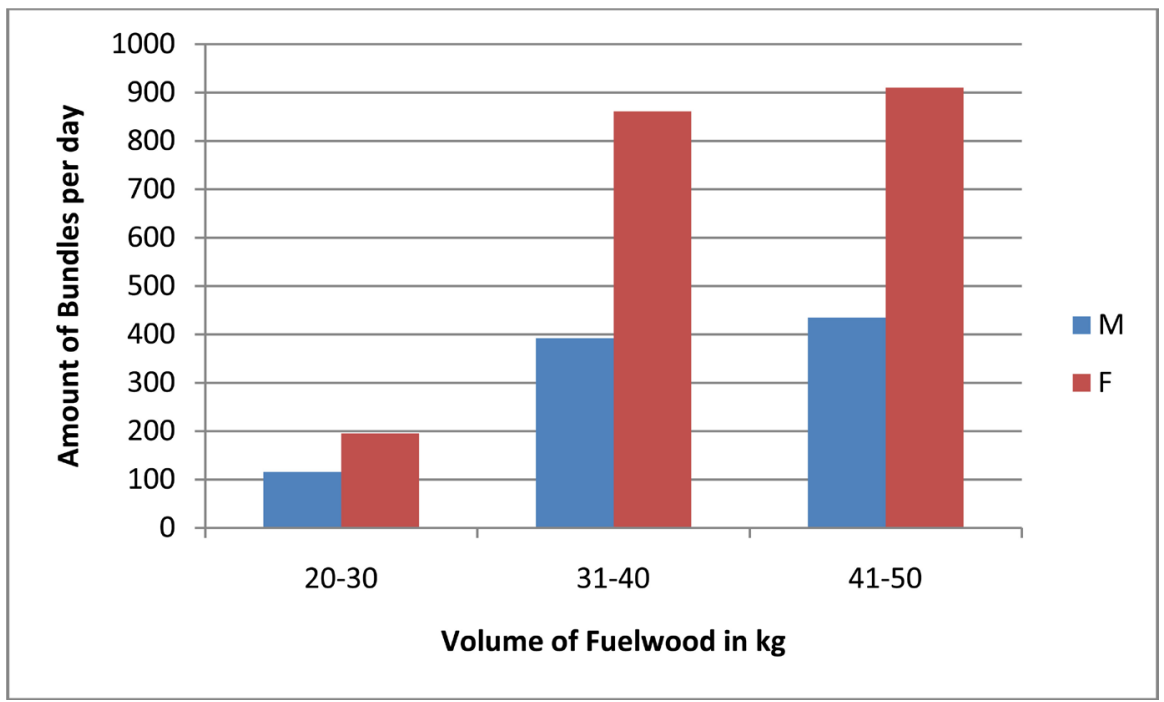

Figure 5. Average amount of fuelwood bundles extracted on daily basis.

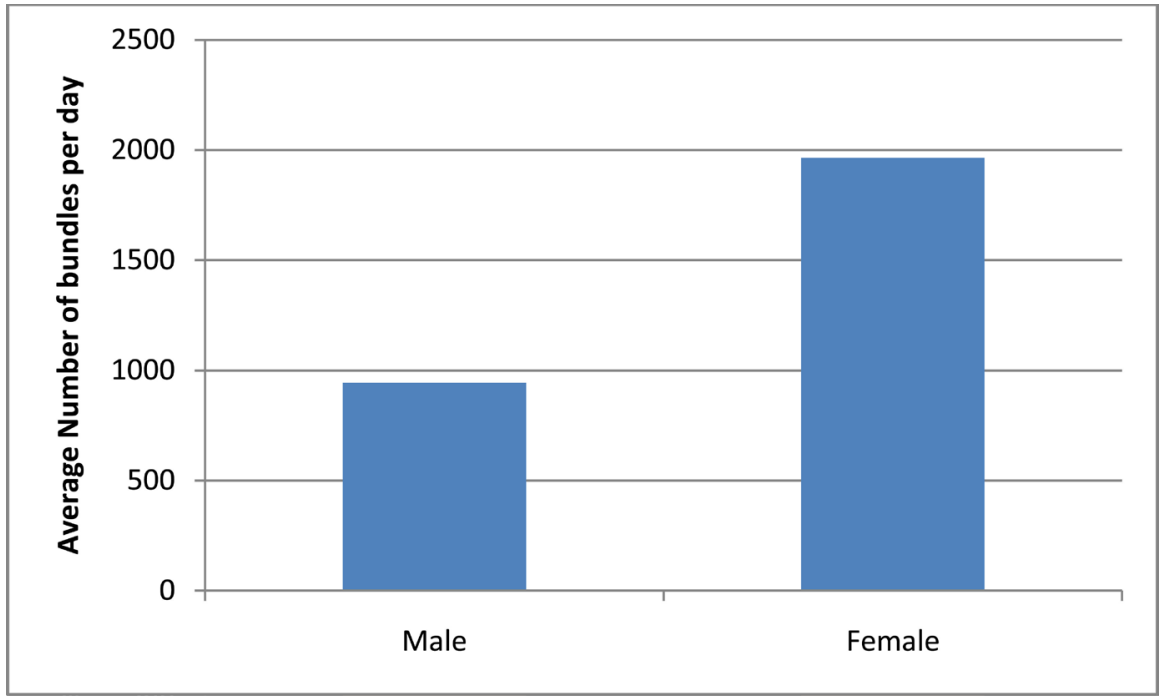

Figure 6. Male-female involvement ratio on fuelwood collection.

The statistical evidences of the survey indicated that, a great proportion of youth and adult age group are engaged in the fuelwood business (Figure 7). If other alternative employment opportunities along with credit and microfinance 
services are strengthened, this human capital can be directed to environment friendly activities. As the zone in general and the district in particular is endowed with natural resources, the development of green jobs and tourism related activities will lower down the traditional reliance of the community on the natural resources of the park as their source of direct income.

As Figure 8 shows, the highest number of fuelwood collectors was observed after $5 \mathrm{pm}$ onwards and that is mainly because of the fact that most of the Park Ranger will be off from work by then and the patrolling activities will be minimal to none. Presently, however, since the patrolling activity is a vital tool of protecting the resources, logistical and other work arrangements could help to combat the clearance of forests and the biodiversity resource potentials of the Park (Table 2).

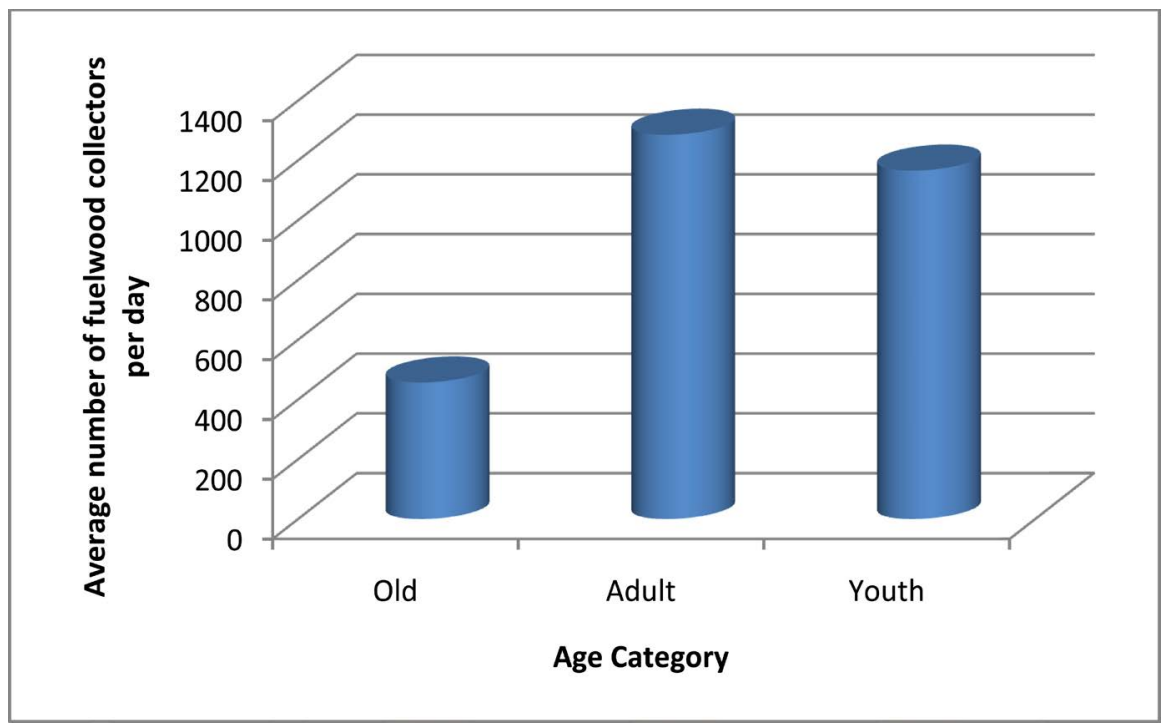

Figure 7. Average number of fuelwood collectors by age category.

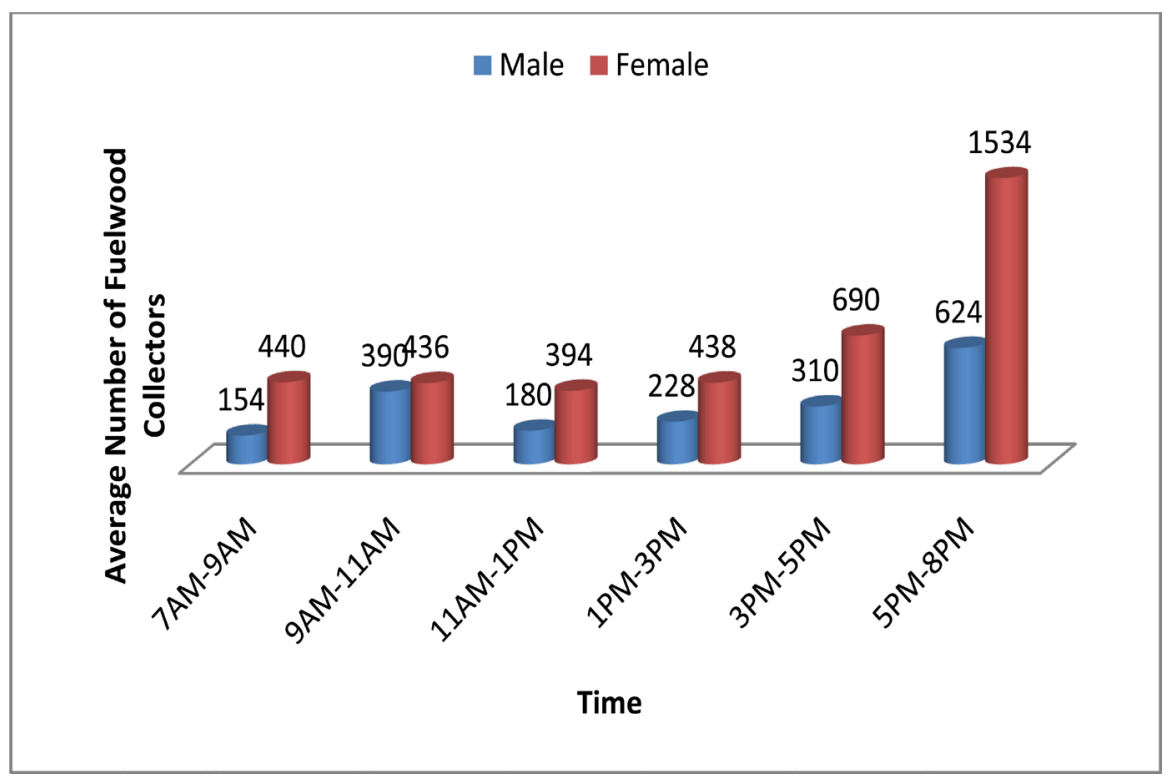

Figure 8. Frequency distribution of fuelwood collectors during the day times. 
Table 2. Average cost of fuel wood and charcoal at Arba Minch city.

\begin{tabular}{cccc}
\hline S.N & Type & Cost $/ \mathrm{Kg} /$ Ethiopian Birr & Cost $/ \mathrm{Kg} / \mathrm{USD}^{*}$ \\
\hline 1 & Fuel wood & 2.00 & 0.09 \\
2 & Charcoal & 4.00 & 0.18 \\
\hline
\end{tabular}

*Exchange rate of $\$ 1$ to 21.87 Ethiopian Birr on July 28, 2016.

\section{National Park's Natural Resources Degradation and the Policy Implications}

According to Ethiopia's Wildlife Development, Conservation and Utilization Regulations No. 163/2008 issued by the Council of Ministers pursuant to Article 5 of the Definition of Powers and Duties of the Executive Organs of the Federal Democratic Republic of Ethiopia Proclamation No. 471/2005 and Article 17(1) of the Wildlife Development, Conservation and Utilization Proclamation No. $541 / 2007$, there are a lot of activities which are prohibited in National Parks, Wildlife Sanctuaries and Wildlife Reserves. Some of which, but not limited to include the following:

a) Hunting or fishing,

b) Picking, disturbing, destroying, damaging or defacing any natural or manmade object,

c) Undertaking agricultural activities or preparing land for cultivation;

d) Allowing to graze and water domestic animals,

e) Allowing, passing through or keeping any domestic or wild animals,

f) Planting, cutting, chopping, removing, taking, damaging or transferring any plant species [16] [17].

However, as a result of weak environmental governance, inefficient law enforcement and poor coordination among the different local, regional and central level institutions, Nech Sar National Park which is recognized by the International Union for the Conservation of Nature (IUCN) as a category II protected area is facing a sever natural resources degradation. Deforestation so as to meet the fuelwood demand of the nearby inhabitants and the increased livestock pressure in the Nech Sar plains are among the challenges to be mentioned which are happening in Nech Sar and other parks like Awash. Hence, as the park is valued for its ecosystem services and values and its magnificent role in climate change and biodiversity conservation that have a local, regional and global implications, a well-coordinated effort, policy and strategic actions that can reverse the current degradation of the park are in high demand so as to manage the natural resources of the park efficiently and hence maintain its contribution for the wider Sustainable Development Goals.

\section{Conclusion}

Forest resources in the protected areas or in other artificial forms are providing vital goods and services for the wellbeing of humanity by being the source of the oxygen, indigenous medicinal sources, creation of employment opportunities and local and regional economic development through tourism. It is a sad fact; 
however, these resources are being affected by the uncontrolled and ever increasing needs of the growing population. In Ethiopia, high environmental degradation resulting from the unsustainable land management practices, weak legislative and monitoring systems and structures are progressively causing in reduced environmental resilience. The Nech Sar National Park woody vegetation is presently under a sever threat of biodiversity loss since a huge amount of trees are being cut everyday so as to meet the household energy demands of the city of Arba Minch and the nearby inhabitants. The wildlife of the park will also be endangered as a result of habitat loses if this threat continues in its current state. Therefore, in order to save the forests of the park from the ongoing deleterious deforestation, all concerned governmental and non-governmental development partners need to intervene in creating conducive policy and strategic environment for the availability of energy saving technologies along with other alternative sources of energy like solar appliances. Woodlots and artificial forestry programmes have to be also envisaged so as to save the native forest resources of the park. It is also worthy to mention as the policy and decision makers of the country for them to consider the placement of a proper environmental governance practice as the precious land resources of the country (such as parks) are being degraded in unsustainable way.

\section{References}

[1] Gottle, A. and Sène, E.-H.M. (1997) Forest Functions Related to Protection and Environmental Conservation. Food and Agriculture Organization of the United $\mathrm{Na}$ tions, Rome.

[2] FAO (Food and Agriculture Organization of the United Nations) (2003) Socio Economic and Ecological Importance of Forests. Food and Agriculture Organization of the United Nations. Forestry Department, Rome.

[3] Wangchuk, S., Siebert, S. and Belsky, J. (2013) Fuelwood Use and Availability in Bhutan: Implications for National Policy and Local Forest Management. Springer Science + Business Media, New York.

[4] Bhatt, B.P. and Sachan, M.S. (2003) Firewood Consumption along an Altitudinal Gradient in Mountain Villages of India. Biomass and Bioenergy, 27, 69-75.

[5] Agarwala, S.P. (2006) Environmental Studies. Alpha Science International Ltd., London.

[6] Carlos, R.M. and Ba Khang, D. (2008) Characterization of Biomass Energy Projects in Southeast Asia. Biomass Bioenergy, 32, 525-532.

https://doi.org/10.1016/j.biombioe.2007.11.005

[7] Hussain, A., Negi, A.K., Singh, R.K., Aziem, S., Iqbal, K. and Pala, N.A. (2016) Comparative Study of Fuelwood Consumption by Semi-Nomadic Pastoral Community and Adjacent Villagers around Corbett Tiger Reserve, India. Indian Forester.

[8] Haile, K., Sandewall, M. and Urgessa, K. (2009) Wood Fuel Demand and Sustainability of Supply in South-Western Ethiopia, Case of Jimma Town.

[9] Asfaw, A. and Demissie, Y. (2012) Sustainable Household Energy for Addis Ababa, Ethiopia. Addis Ababa University Horn of Africa Regional Environment Centre and Network Addis Ababa, Ethiopia. 
[10] Desse, A.M. (2015) Summary of Attractions, Challenges, Research, Management and Partnership Issues on Nech Sar National Park. Arba Minch, Ethiopia.

[11] EWCA (Ethiopian Wildlife Conservation Authority) (2015) Location Map of Nech Sar National Park (on CD), Addis Ababa, Ethiopia.

[12] NSNP (Nech Sar National Park) (2016) Facts and Figures of Nech Sar National Park. Addis Ababa, Ethiopia.

[13] Shibru, S. (2016) Responses of Vegetation, Small Mammals and Large Herbivores to Human Induced Pressures in the Savannah Plains of Nech Sar National Park, South Ethiopia Rift Valley. University of ANTWERP, Belgium Faculty of Science Department of Biology, PhD Dissertation.

[14] GGZWMEO (Gamo Gofa Zone Water, Mines and Energy Office) (2016) List of Fuel Saving Stove Producers in Gamo Gofa Zone. Arba Minch, Ethiopia.

[15] FDRE-PCC (Federal Democratic Republic of Ethiopia, Population Census Commission) (2008) Summary and Statistical Report of the 2007 Population and Housing Census. Addis Ababa, Ethiopia.

[16] CM (Council of Ministers) (2008) Wildlife Development, Conservation and Utilization Council of Ministers Regulations No. 163/2008. Federal Democratic Republic of Ethiopia Proclamation No. 471/2005 and Article 17(1) of the Wildlife Development, Conservation and Utilization Proclamation No. 541/2007. Addis Ababa, Ethiopia.

[17] FDRE (Federal Democratic Republic of Ethiopia) (2007) Development, Conservation and Utilization of Wildlife Proclamation No. 541/2007. Addis Ababa, Ethiopia.

Submit or recommend next manuscript to OALib Journal and we will provide best service for you:

- Publication frequency: Monthly

- 9 subject areas of science, technology and medicine

- Fair and rigorous peer-review system

- Fast publication process

- Article promotion in various social networking sites (LinkedIn, Facebook, Twitter, etc.)

- Maximum dissemination of your research work

Submit Your Paper Online: Click Here to Submit

Or Contact service@oalib.com 